\title{
Transfer of Active Ingredients from Plant Protection Products to a Honeybee (Apis mellifera F.) Hive from Winter Oilseed Rape Crops Protected with Conventional Methods
}

\author{
Bartosz Piechowicz $^{1}$, Przemysław Grodzicki²*, Magdalena Podbielska ${ }^{1}$, \\ Natalia Tyrka ${ }^{1}$, Małgorzata Śliwa ${ }^{1}$ \\ ${ }^{1}$ Faculty of Biotechnology, Department of Analytical Chemistry, University of Rzeszów, \\ Pigonia 1, 35-310 Rzeszów, Poland \\ ${ }^{2}$ Faculty of Biology and Environmental Protection, Department of Animal Physiology, Nicolaus Copernicus University, \\ Lwowska 1, 87-100 Toruń, Poland
}

Received: 28 June 2017

Accepted: 10 August 2017

\begin{abstract}
Field tests verified and evaluated a pesticide's active ingredient transfer to honeybee hives from rapeseed crops protected according to current programs. Samples of rapeseed flowers, leaves, and soil were collected, as well as of worker honeybees, the brood, and honey from hives located in the crops. They were evaluated for the presence of four insecticides and five fungicides. In flower samples and leaf samples flutriafol at plantation 1 and azoxystrobin at plantation 2 were found at the highest levels. In honeybees and in the brood, five AIs were detected at plantation 1, of which the highest levels were observed for flutriafol $(25.5 \mu \mathrm{g} / \mathrm{kg}$ of honeybee) and picoxystrobin $(7.3 \mu \mathrm{g} / \mathrm{kg}$ of brood). At plantation 2, residues of three and two AIs were detected in honeybees and in the brood, respectively, of which chlorpyrifos was at the highest level $(19.5 \mu \mathrm{g} / \mathrm{kg}$ of honeybee, and $2.8 \mu \mathrm{g} / \mathrm{kg}$ of brood). For both plantations, residues of three AIs were found in honey. The AI levels in honey did not exceed $3.8 \%$ of acceptable maximum residue level at plantation 1 , and $2.8 \%$ at plantation 2 . The percentage of acceptable daily intake did not exceed $0.01 \%$.
\end{abstract}

Keywords: honeybee, honey, pesticide transfer, oilseed rape, acceptable daily intake, maximum residue level

\section{Introduction}

Rapeseed (Brassica napus L. var. Napus) is a plant pollinated by insects. In climatic conditions of Poland,

*e-mail: grodzick@umk.pl it is visited mainly by honeybees (Apis mellifera). In 2015, 947,000 hectares were sown with rape, producing 2.7 million tons of grain [1]. Every year, significant losses in the yield of this plant are observed, caused mainly by pathogenic fungi, including: Plasmodiophora brassicae Wor., Leptosphaeria biglobosa Shoem. et Brun, L. maculans Desm., Alternaria brassicae Berk., 
Table 1. Pesticide spraying program carried out on rapeseed plantation 1, field 1, 2015.

\begin{tabular}{|c|c|c|c|c|c|}
\hline $\begin{array}{c}\text { Date of } \\
\text { treatment }\end{array}$ & $\begin{array}{c}\text { PPP, } \\
\text { Trade name }\end{array}$ & $\begin{array}{c}\text { AI, } \\
\text { Common name }\end{array}$ & $\begin{array}{c}\text { Dose of AI } \\
(\mathrm{L}, \mathrm{kg} / \mathrm{ha})\end{array}$ & $\begin{array}{c}\text { MRL of AI in honey } \\
(\mu \mathrm{g} / \mathrm{kg})\end{array}$ & $\begin{array}{c}\text { ADI of AI } \\
(\mu \mathrm{gg}-1 \mathrm{~b} . \mathrm{w} .)\end{array}$ \\
\hline March 11 & Difo 250 EC (F)* & difenoconazole & 0.25 & 50.0 & 10.0 \\
\hline April 10 & Dursban 480 EC (I) & chlorpyrifos & 0.29 & 50.0 & 1.0 \\
\hline April 21 & Caryx 240 SL (F) & $\begin{array}{c}\text { mepiquat chloride** } \\
\text { metconazole** }\end{array}$ & $\begin{array}{c}0.26 \\
0.036\end{array}$ & 50.0 & 50.0 \\
\hline May 07 & Impact 125 SC (F) & flutriafol & 0.10 & 50.0 & 10.0 \\
\hline May 07 & Galileo 250 SC (F) & picoxystrobin & 0.13 & 50.0 & 10.0 \\
\hline May 08 & Proteus 110 OD (I) & thiacloprid & 0.06 & 200.0 & 10.0 \\
\hline May 14 & First day of sampling & & 0.006 & 30.0 & 10.0 \\
\hline May 15 & Cyperkill max 500 EC & cypermethrin & 0.05 & 50.0 & 50.0 \\
\hline May 20 & Sumi-alpha 050 EC (I) & esfenvalerate & 0.010 & 50.0 & 17.5 \\
\hline
\end{tabular}

*I (insecticide), F (fungicide); **not determined

Sclerotinium sp., Pyrenopeziza brassicae B. Sutton et Rawl., Botrytis cinerea Pers. and Verticillium sp., and by the pest insects: Ceutorhynchus napi Gyll., Ceutorhynchus quadridens Panz., Meligethes aeneus F., Brevicoryne brassicae L., Ceutorrhynchus assimilis Payk, and Athalia colibri Christ. In warm and humid weather conditions these losses can even reach $50 \%$ [2]. For the above-mentioned reasons, rapeseed belongs to the most intensively chemically protected crops, which may pose a threat to the insects pollinating this plant, including honeybees - insects with extremely poor resistance to the active ingredients (AIs) of plant protection products (PPPs) [3-5]. These substances can be transferred by bees to their hives on their bodies or with the food they collect.

The aim of our study was to verify whether AIs of PPPs used at the rapeseed plantation protected against insects and fungal deseases can be transferred to hives located in the direct vincinity of the crops. In terms of formal and legal aspects, the safety of consumption of honey obtained from the aforementioned hives was also assessed.

\section{Material and Methods}

\section{Field Trials}

Field trials were performed from 14 May to 11 June 2015 (five sampling dates, at plantation 1, trial 1), and from 15 May to 10 June 2015 (four sampling dates at plantation 2, trial 2) in the following villages: Młyny (Kujawsko-Pomorskie, Mogilno District, Strzelno Municipality (trial 1); and Papowo-Osieki (KujawskoPomorskie, Toruń District, Łysomice commune (trial 2).

Residues of PPP AIs were determined in samples of adult worker bees, brood, and honey collected in each case from hives located in the nearest neighbourhood of plantations, and of flowers and leaves, as well as of soil layer adjacent the cultivated plants (Table 2 and 5) to a depth of $20 \mathrm{~cm}$. Additionally, flowers were collected from other rapeseed crops in the vicinity of plantation 1 , located within $200 \mathrm{~m}$ of the studied hive (field 2, Table 3). The protection programs for both plantations are shown in Tables 1 and 4 . The protection program used in field 2 (plantation 1) (Table 3) was not known.

\section{Extracting Pesticide Residues from Worker Bee, Brood, and Honey Samples}

A sample of 5 g lyophilized insects (Labconco Freezone 2.5 freeze dryer, Labconco, USA) (pressure 0.024 mbar, $50^{\circ} \mathrm{C}$, time 168 hours) or $5 \mathrm{~g}$ of honey, was shaken in 10 $\mathrm{mL}$ of water, $3 \mathrm{~mL}$ of petroleum ether (Chempur, Poland) and $10 \mathrm{~mL}$ of acetonitrile (Chempur, Poland). Then a mixture of salts was added containing $4 \mathrm{~g}$ of anhydrous magnesium sulfate(VI) (Chempur, Poland), 1 g sodium chloride (Chempur, Poland), $1 \mathrm{~g}$ of trisodium citrate (Chempur, Poland), and $0.5 \mathrm{~g}$ of sesquihydrate disodium hydrogen citrate (Chempur, Poland). The contents were shaken for 2 minutes and centrifuged for 5 minutes at $3,500 \mathrm{RPM}$ at $21^{\circ} \mathrm{C}$. Six $\mathrm{mL}$ of the acetonitrile phase were transferred to a polypropylene tube containing $150 \mathrm{mg}$ of primary secondary amine (PSA; Agilent, USA) and $900 \mathrm{mg}$ of anhydrous sodium sulphate(VI) (Chempur, Poland). The extract was vigorously shaken for two minutes and centrifuged for 5 minutes under analogous conditions as before. Four $\mathrm{mL}$ of the obtained extract were collected and transferred into a glass tube, then evaporated to dryness on a rotary evaporator Heidolph Laborota 4000 Efficient (Heidolph, Germany), and dissolved in $4 \mathrm{ml}$ of petroleum ether (Chempur, Poland). 
Table 2. Average residue levels $( \pm \mathrm{SD})$ of AIs of PPPs found in flowers, leaves, soil, and worker honeybees, brood, and honey; plantation 1 , field 1 .

\begin{tabular}{|c|c|c|c|c|c|c|c|}
\hline Sampling date & Chlorpyrifos & Esfenvalerate & Cypermethrin & Difenoconazole & Picoxystrobin & Deltamethrin & Flutriafol \\
\hline \multicolumn{8}{|c|}{ Flowers - surface residues ( $\mu \mathrm{g} /$ single flower) } \\
\hline May 14 & $0.017 \pm 0.007$ & $<\mathrm{LOQ}$ & $<\mathrm{LOQ}$ & $0.002 \pm 0.003$ & $0.047 \pm 0.022$ & $0.007 \pm 0.005$ & $0.058 \pm 0.031$ \\
\hline May 21 & $0.007 \pm 0.002$ & $0.012 \pm 0.011$ & $0.018 \pm 0.013$ & $0.001 \pm 0.002$ & $0.002 \pm 0.003$ & $0.002 \pm 0.001$ & $<\mathrm{LOQ}$ \\
\hline May 28 & $0.003 \pm 0.001$ & $0.009 \pm 0.011$ & $0.004 \pm 0.004$ & $<\mathrm{LOQ}$ & $<\mathrm{LOQ}$ & $<\mathrm{LOQ}$ & $<\mathrm{LOQ}$ \\
\hline June 03 & $0.003 \pm 0.003$ & $0.001 \pm 0.001$ & $0.005 \pm 0.006$ & $<\mathrm{LOQ}$ & $<\mathrm{LOQ}$ & $<\mathrm{LOQ}$ & $<\mathrm{LOQ}$ \\
\hline June 11 & $0.004 \pm 0.002$ & $<\mathrm{LOQ}$ & $<\mathrm{LOQ}$ & $<$ LOQ & $<\mathrm{LOQ}$ & $<$ LOQ & $<\mathrm{LOQ}$ \\
\hline \multicolumn{8}{|c|}{ Flowers - incurred residues ( $\mu \mathrm{g} /$ single flower) } \\
\hline May 14 & $0.003 \pm 0.002$ & $<\mathrm{LOQ}$ & $<\mathrm{LOQ}$ & $0.003 \pm 0.003$ & $<\mathrm{LOQ}$ & $<\mathrm{LOQ}$ & $<\mathrm{LOQ}$ \\
\hline May 21 & $0.006 \pm 0.002$ & $0.001 \pm 0.002$ & $<\mathrm{LOQ}$ & $0.001 \pm 0.001$ & $<\mathrm{LOQ}$ & $<\mathrm{LOQ}$ & $0.012 \pm 0.004$ \\
\hline May 28 & $0.006 \pm 0.001$ & $<\mathrm{LOQ}$ & $<\mathrm{LOQ}$ & $\begin{array}{c}0.001 \\
\pm 0.000\end{array}$ & $<\mathrm{LOQ}$ & $<\mathrm{LOQ}$ & $<\mathrm{LOQ}$ \\
\hline June 03 & $0.006 \pm 0.002$ & $<\mathrm{LOQ}$ & $<\mathrm{LOQ}$ & $<\mathrm{LOQ}$ & $<\mathrm{LOQ}$ & $<\mathrm{LOQ}$ & $<\mathrm{LOQ}$ \\
\hline June 11 & $0.007 \pm 0.000$ & $<\mathrm{LOQ}$ & $0.001 \pm 0.001$ & $<\mathrm{LOQ}$ & $<\mathrm{LOQ}$ & $<\mathrm{LOQ}$ & $<\mathrm{LOQ}$ \\
\hline \multicolumn{8}{|c|}{ Leaves - surface residues $\left(\mu \mathrm{g} / \mathrm{cm}^{2}\right)$} \\
\hline May 14 & $0.018 \pm 0.004$ & $<\mathrm{LOQ}$ & $<\mathrm{LOQ}$ & $<\mathrm{LOQ}$ & $0.018 \pm 0.022$ & $0.016 \pm 0.016$ & $0.021 \pm 0.014$ \\
\hline May 21 & $0.005 \pm 0.003$ & $0.039 \pm 0.019$ & $0.012 \pm 0.011$ & $<$ LOQ & $0.012 \pm 0.009$ & $0.009 \pm 0.011$ & $0.013 \pm 0.007$ \\
\hline May 28 & $0.003 \pm 0.001$ & $0.021 \pm 0.018$ & $0.010 \pm 0.007$ & $<\mathrm{LOQ}$ & $<\mathrm{LOQ}$ & $0.004 \pm 0.004$ & $0.004 \pm 0.002$ \\
\hline June 03 & $0.003 \pm 0.003$ & $0.004 \pm 0.003$ & $0.003 \pm 0.001$ & $<$ LOQ & $<\mathrm{LOQ}$ & $0.002 \pm 0.002$ & $0.003 \pm 0.002$ \\
\hline June 11 & $0.002 \pm 0.001$ & $0.001 \pm 0.001$ & $0.001 \pm 0.000$ & $<\mathrm{LOQ}$ & $<\mathrm{LOQ}$ & $<\mathrm{LOQ}$ & $<\mathrm{LOQ}$ \\
\hline \multicolumn{8}{|c|}{ Soil from a $20 \mathrm{~cm}$ profile $(\mu \mathrm{g} / \mathrm{kg})$} \\
\hline May 14 & $20.1 \pm 0.0$ & $<\mathrm{LOQ}$ & $<\mathrm{LOQ}$ & $<\mathrm{LOQ}$ & $<$ LOQ & $21.8 \pm 19.1$ & $<\mathrm{LOQ}$ \\
\hline May 21 & $13.0 \pm 2.5$ & $10.2 \pm 11.1$ & $<\mathrm{LOQ}$ & $<\mathrm{LOQ}$ & $<$ LOQ & $11.2 \pm 3.2$ & $<\mathrm{LOQ}$ \\
\hline May 28 & $5.4 \pm 2.2$ & $7.6 \pm 4.2$ & $<\mathrm{LOQ}$ & $<\mathrm{LOQ}$ & $<$ LOQ & $6.4 \pm 5.9$ & $<\mathrm{LOQ}$ \\
\hline June 03 & $5.3 \pm 2.2$ & $2.1 \pm 1.7$ & $<\mathrm{LOQ}$ & $<\mathrm{LOQ}$ & $<\mathrm{LOQ}$ & $<\mathrm{LOQ}$ & $<\mathrm{LOQ}$ \\
\hline June 11 & $7.2 \pm 3.7$ & $<\mathrm{LOQ}$ & $<\mathrm{LOQ}$ & $<\mathrm{LOQ}$ & $<\mathrm{LOQ}$ & $<\mathrm{LOQ}$ & $<\mathrm{LOQ}$ \\
\hline \multicolumn{8}{|c|}{ Worker honeybees $(\mu \mathrm{g} / \mathrm{kg})$} \\
\hline May 14 & $10.2 \pm 8.2$ & $<\mathrm{LOQ}$ & $<\mathrm{LOQ}$ & $2.0 \pm 3.5$ & $<\mathrm{LOQ}$ & $<\mathrm{LOQ}$ & $<\mathrm{LOQ}$ \\
\hline May 21 & $8.9 \pm 2.4$ & $2.5 \pm 0.7$ & $0.3 \pm 0.6$ & $1.1 \pm 0.2$ & $<\mathrm{LOQ}$ & $<\mathrm{LOQ}$ & $<\mathrm{LOQ}$ \\
\hline May 28 & $5.5 \pm 2.5$ & $0.1 \pm 0.1$ & $0.1 \pm 0.1$ & $1.1 \pm 1.0$ & $<\mathrm{LOQ}$ & $<$ LOQ & $<\mathrm{LOQ}$ \\
\hline June 03 & $4.4 \pm 3.5$ & $0.2 \pm 0.2$ & $<\mathrm{LOQ}$ & $1.9 \pm 0.7$ & $<\mathrm{LOQ}$ & $<$ LOQ & $25.5 \pm 22.1$ \\
\hline June 11 & $2.4 \pm 1.3$ & $0.1 \pm 0.2$ & $<\mathrm{LOQ}$ & $0.2 \pm 0.5$ & $<\mathrm{LOQ}$ & $<$ LOQ & $<\mathrm{LOQ}$ \\
\hline \multicolumn{8}{|c|}{ Worker brood $(\mu \mathrm{g} / \mathrm{kg})$} \\
\hline May 14 & $0.5 \pm 0.9$ & $<\mathrm{LOQ}$ & $<\mathrm{LOQ}$ & $<\mathrm{LOQ}$ & $<\mathrm{LOQ}$ & $0.2 \pm 0.3$ & $<\mathrm{LOQ}$ \\
\hline May 21 & $3.4 \pm 1.7$ & $<\mathrm{LOQ}$ & $<\mathrm{LOQ}$ & $1.9 \pm 2.2$ & $0.8 \pm 1.6$ & $<\mathrm{LOQ}$ & $<\mathrm{LOQ}$ \\
\hline May 28 & $1.0 \pm 0.5$ & $0.2 \pm 0.2$ & $<\mathrm{LOQ}$ & $0.6 \pm 0.7$ & $7.3 \pm 4.6$ & $<\mathrm{LOQ}$ & $<\mathrm{LOQ}$ \\
\hline June 03 & $1.8 \pm 2.3$ & $<\mathrm{LOQ}$ & $<\mathrm{LOQ}$ & $<\mathrm{LOQ}$ & $<\mathrm{LOQ}$ & $<$ LOQ & $<\mathrm{LOQ}$ \\
\hline June 11 & $2.9 \pm 4.2$ & $<$ LOQ & $<$ LOQ & $0.2 \pm 0.4$ & $<\mathrm{LOQ}$ & $<\mathrm{LOQ}$ & $<\mathrm{LOQ}$ \\
\hline
\end{tabular}


Table 2. Continued.

\begin{tabular}{|c|c|c|c|c|c|c|c|}
\hline \multicolumn{8}{|c|}{ Honey $(\mu \mathrm{g} / \mathrm{kg})$} \\
\hline May 14 & $1.7 \pm 0.5$ & $<\mathrm{LOQ}$ & $<\mathrm{LOQ}$ & $1.3 \pm 2.6$ & $<$ LOQ & $<\mathrm{LOQ}$ & $<\mathrm{LOQ}$ \\
\hline May 21 & $0.6 \pm 0.6$ & $<\mathrm{LOQ}$ & $0.4 \pm 0.5$ & $1.3 \pm 2.6$ & $<$ LOQ & $<\mathrm{LOQ}$ & $<\mathrm{LOQ}$ \\
\hline May 28 & $1.7 \pm 1.7$ & $<\mathrm{LOQ}$ & $0.3 \pm 0.5$ & $1.9 \pm 3.9$ & $<$ LOQ & $<\mathrm{LOQ}$ & $<\mathrm{LOQ}$ \\
\hline June 03 & $0.6 \pm 0.2$ & $<\mathrm{LOQ}$ & $<\mathrm{LOQ}$ & $<\mathrm{LOQ}$ & $<$ LOQ & $<\mathrm{LOQ}$ & $<\mathrm{LOQ}$ \\
\hline June 11 & $0.6 \pm 0.4$ & $<\mathrm{LOQ}$ & $<\mathrm{LOQ}$ & $0.9 \pm 1.8$ & $<\mathrm{LOQ}$ & $<\mathrm{LOQ}$ & $<\mathrm{LOQ}$ \\
\hline
\end{tabular}

Table 3. Average residue levels $( \pm \mathrm{SD})$ of AIs of PPPs found in flowers; Plantation 1, field 2.

\begin{tabular}{|c|c|c|c|c|c|c|c|}
\hline Sampling date & Chlorpyrifos & Esfenvalerate & Difenoconazole & Picoxystrobin & Deltamethrin & Flutriafol \\
\hline \multicolumn{7}{|c|}{ Flowers - surface residues $(\mu \mathrm{g} /$ single flower $)$} \\
\hline May 14 & $0.018 \pm 0.003$ & $0.003 \pm 0.001$ & $<$ LOQ & $0.012 \pm 0.002$ & $0.010 \pm 0.002$ & $0.013 \pm 0.002$ \\
\hline May 21 & $0.007 \pm 0.001$ & $0.002 \pm 0.002$ & $0.001 \pm 0.001$ & $0.002 \pm 0.002$ & $0.001 \pm 0.001$ & $0.010 \pm 0.002$ \\
\hline May 28 & $0.005 \pm 0.001$ & $0.002 \pm 0.001$ & $<$ LOQ & $0.001 \pm 0.004$ & $<$ LOQ & $<$ LOQ \\
\hline June 03 & $0.004 \pm 0.000$ & $<$ LOQ & $<$ LOQ & $<$ LOQ & $<$ LOQ & $0.011 \pm 0.085$ \\
\hline June 11 & $0.007 \pm 0.002$ & $<$ LOQ & $<$ LOQ & $<$ LOQ & $<$ LOQ & $<$ LOQ \\
\hline
\end{tabular}

Extracting Surface Pesticide Residues from Leaf and Flower Samples

Eight flowers, or 16 discs of $0.7 \mathrm{~cm}$ in diameter obtained from the 16 rapeseed leaves (flowers and leaves were collected from randomly selected plants from the whole plantation area), were put in bottles with ether petroleum (c.a. $30 \mathrm{~mL}$ Chempur, Poland). On each sampling date, four samples of flowers and leaves were collected from each plantation. After transportation to the laboratory the contents of each bottle were shaken for about 0.5 minutes. Then to remove traces of moisture they were filtered through anhydrous sodium sulfate(VI) to a $50 \mathrm{~mL}$ measuring flask. The leaf discs/pieces of flowers were washed three times with $5 \mathrm{~mL}$ ether petroleum. The obtained washings were used to wash the filter paper and the sulphate. Then they were filled up to a volume of $50 \mathrm{~mL}$ and placed in a refrigerator until chromatographic analysis.

\section{Extracting Internal Pesticide Residues from Flower Samples}

Flowers extracted by ether petroleum were transferred to a Waring Commercial 8010 EG blender container (Waring, USA) (100 mL of water were added to each sample), and incurred residues were extracted with $200 \mathrm{~mL}$ of acetone (Chempur, Poland) and filtered on a Büchner's funnel under vacuum. The blender jar was flushed with $50 \mathrm{~mL}$ of acetone and the washings were used to wash the filter cake. One-fifth of the obtained filtrate volume was used for further analysis. It was placed in a

Table 4. Pesticide spraying program carried out on rapeseed plantation 2 in 2015.

\begin{tabular}{|c|c|c|c|c|c|}
\hline $\begin{array}{c}\text { Date of } \\
\text { treatment }\end{array}$ & $\begin{array}{c}\text { PPP, } \\
\text { Trade name }\end{array}$ & $\begin{array}{c}\text { AI, } \\
\text { Common name }\end{array}$ & $\begin{array}{c}\text { Dose of AI } \\
(\mathrm{L}, \mathrm{kg} / \mathrm{ha})\end{array}$ & $\begin{array}{c}\text { MRL of AI in honey } \\
(\mu \mathrm{g} / \mathrm{kg})\end{array}$ & $\begin{array}{c}\text { ADI of AI } \\
\left(\mu \mathrm{g} \mathrm{kg} \mathrm{k}^{-1} \mathrm{~b} . \mathrm{w} .\right)\end{array}$ \\
\hline March 23 & Dursban 480 EC (I)* & chlorpyrifos & 0.29 & 50.0 & 1.0 \\
\hline March 23 & Topsin 500 SC (F) & thiophanate-methyl** & 0.50 & 1000.0 & 80.0 \\
\hline \multirow{2}{*}{ April 10 } & Toprex 375 SC (F) & $\begin{array}{c}\text { difenoconazole } \\
\text { paclobutrazol** }\end{array}$ & 0.10 & 50.0 & 10.0 \\
\hline \multirow{2}{*}{ April 15 } & Nurelle D550 (I) & $\begin{array}{c}\text { chlorpyrifos } \\
\text { cypermethrin }\end{array}$ & 0.05 & 50.0 & 1.0 \\
\hline April 23 & Mospilan 20 SP (I) & acetamiprid & 0,024 & 50.0 & 70.0 \\
\hline \multirow{2}{*}{ May 08 } & Amistar Xtra 280 SC & azoxystrobin & 0.16 & 50.0 & 200.0 \\
\hline
\end{tabular}

*I (insecticide), F (fungicide); **not determined 
separatory funnel together with $100 \mathrm{~mL}$ of $2.5 \%$ sodium sulphate(VI) (Chempur, Poland) solution. Pesticide residues were extracted three times with $20 \mathrm{~mL}, 10 \mathrm{~mL}$, and $10 \mathrm{~mL}$ of dichloromethane (Chempur, Poland). The combined extracts were evaporated to dryness, dissolved in approximately $10 \mathrm{~mL}$ of petroleum ether, and purified on a Florisil (Chempur, Poland) column [6-7]. Pesticides were eluted with $70 \mathrm{~mL}$ of ethyl ether-petroleum ether (Chempur, Poland) mixture $(3: 7(\mathrm{v} / \mathrm{v}))$, and then with $70 \mathrm{~mL}$ mixture of acetone-petroleum ether mixture (3:7 $(\mathrm{v} / \mathrm{v}))$. The solvents were evaporated to dryness and the residues were transferred quantitatively, with petroleum ether, to the $10 \mathrm{~mL}$ measuring flask.

\section{Extracting Residues from Soil Samples}

Laboratory samples of soil were air dried and pulverized with a Testchem LMG grinder (Testchem Sp. z.o.o., Poland), carefully stirred, and then $20 \mathrm{~g}$ analytical portions were collected. Analytical portions were agitated for one hour with $50 \mathrm{~mL}$ of dichloromethane:acetone (9:1 v/v) mixture on a GFL 3006 shaker (GFL, Germany). Then, the samples were left for 10 minutes and the extract was decanted through a layer of anhydrous sodium sulphate (VI) and placed in the funnel. The soil samples were washed twice with $20 \mathrm{~mL}$ of dichloromethane. The combined extracts were evaporated to dryness on a rotary evaporator Heidolph Laborota 4000 Efficient, and the residues were dissolved in approximately $10 \mathrm{~mL}$ of petroleum ether. The resulting extracts were purified on a Florisil column [6-7], and residues were eluted with $70 \mathrm{~mL}$ of diethyl ether and petroleum ether $(3: 7(\mathrm{v} / \mathrm{v}))$, and then with $70 \mathrm{~mL}$ of acetone and petroleum ether (3:7 $(\mathrm{v} / \mathrm{v}))$. The combined eluates were evaporated to dryness and the residues were transferred quantitatively, with petroleum ether, to a $10 \mathrm{~mL}$ measuring flask.

\section{Chromatographic Analysis}

The obtained extracts were analysed using an Agilent 7890 (Agilent, USA) gas chromatograph equipped with micro-cell electron capture detector ( $\mu \mathrm{ECD})$. The chromatograph was controlled by ChemStation software and equipped with an autosampler and an HP$5 \mathrm{MS} 30 \mathrm{~m} \times 0.32 \mathrm{~mm} \times 0.25 \mathrm{~mm}$ column . The following conditions of instrumental analysis were used: $\mu \mathrm{ECD}$ detector at $290^{\circ} \mathrm{C}$ and injector temperature of $250^{\circ} \mathrm{C}$. The oven temperature was programmed as follows: $100^{\circ} \mathrm{C}$ for $0 \mathrm{~min} \rightarrow 10^{\circ} \mathrm{C} / \mathrm{min} \rightarrow 180^{\circ} \mathrm{C}$ for $4 \mathrm{~min} \rightarrow 3^{\circ} \mathrm{C} / \mathrm{min} \rightarrow$ $220^{\circ} \mathrm{C}$ for $15 \mathrm{~min} \rightarrow 10^{\circ} \mathrm{C} / \mathrm{min} \rightarrow 260^{\circ} \mathrm{C}$ for $11 \mathrm{~min}$; total time of analysis was 55.3 minutes. The injection volume was $1 \mu \mathrm{L}$.

\section{Data Analysis}

The residue of a given substance $\left(\mathrm{R}_{\mathrm{i}}\right)$ found in one of four honey samples collected on a given sampling date was divided by its respective maximum residue level (MRL). Then the mean percentage of the MRL was calculated using Equation 1:

$$
\% M R L=100 \sum_{i=1}^{n} \frac{R_{i}}{M R L}
$$

...where $\mathrm{R}_{\mathrm{i}}$ corresponded to the residue level of a given substance found in one of four samples, and the MRL was a legally accepted MRL currently in force in the European Union (EU) [8]. The percentage MRL values for all substances (so-called multiple residues) found in each of four samples were summed and then their total percentages of the respective MRL values were estimated.

Using the residue level of a given substance $\left(R_{i}\right)$ and assuming a body weight (b.w.) of $76 \mathrm{~kg}$ as well a daily consumption (C) of honey by an adult Polish consumer of $0.00157 \mathrm{~kg}$ [9-10], long-term dietary intake along with honey was calculated and expressed as a percentage of acceptable daily intake (ADI ) [8], and then the mean percentages of the respective ADI values for each of four samples collected on relevant sampling days were calculated. Similarly, assuming the additive effect of various pesticides on the human body, the total long-term daily intakes (in \%ADI) of all substances were calculated according to Equation 2:

$$
\% A D I=100 \frac{C}{b . w .} \sum_{i=1}^{n} \frac{R_{i}}{A D I}
$$

Finally, on the basis of the calculated long-term daily intake with honey of a given substance $\left(\mathrm{R}_{\mathrm{i}}\right)$ expressed as percentage of ADI and daily honey consumption $(\mathrm{C}=0.00157 \mathrm{~kg})$ by an adult Polish consumer, the safe honey consumption level $\left(\mathrm{C}_{\text {safe }}\right.$, as $\left.\mathrm{kg}\right)$ could be easily calculated using Equation 3:

$$
C_{\text {safe }}=100 \frac{C}{\% A D I}
$$

\section{Results and Discussion}

In general, average pesticide recoveries in foods of plant origin should be within the range $70-120 \%$, and the repeatability should be below or equal to $20 \%$ [11]. In our study, satisfactory values of both of these parameters were obtained for nine AI PPPs found in seven types of samples. In the case of azoxystrobin (leaves), deltamethrin (brood and honey), flutriafol (worker honeybees), and cyproconazole (worker honeybees and brood), the recoveries exceeded the range of $70-120 \%$ and amounted to $144.8 \%, 67.3 \%$, $62.5 \%, 157.1 \%, 170.3$, and $277.8 \%$, respectively. The limits of quantification (LOQ) of all studied substances were: $0.001 \mu \mathrm{g} /$ single flower, $0.001 \mu \mathrm{g} / \mathrm{cm}^{2}$ of leaves, and $0.2 \mu \mathrm{g} / \mathrm{kg}$ of soil, worker honeybee, brood, and honey. Because of very low recoveries of acetamiprid (3.1-30.4\%) and thiaclo-prid (1.8-17.5\%) in all matrices, the residues of those AIs were not considered in the analysis. 
Table 5. Average residue levels $( \pm \mathrm{SD})$ of AIs of PPPs found in flowers, leaves, soil, and worker honeybees, brood and honey; Plantation 2.

\begin{tabular}{|c|c|c|c|c|c|}
\hline Sampling date & Chlorpyrifos & Cyproconazole & Cypermethrin & Difenoconazole & Azoxystrobin \\
\hline \multicolumn{6}{|c|}{ Flowers - surface residues ( $\mu \mathrm{g} /$ single flower) } \\
\hline May 15 & $0.010 \pm 0.015$ & $0.035 \pm 0.070$ & $0.003 \pm 0.007$ & $0.029 \pm 0.023$ & $0.037 \pm 0.021$ \\
\hline May 20 & $0.007 \pm 0.002$ & $0.028 \pm 0.019$ & $0.002 \pm 0.003$ & $0.024 \pm 0.048$ & $0.004 \pm 0.003$ \\
\hline May 29 & $0.003 \pm 0.002$ & $<$ LOQ & $<\mathrm{LOQ}$ & $0.013 \pm 0.026$ & $0.001 \pm 0.001$ \\
\hline June 10 & $0.003 \pm 0.002$ & $<$ LOQ & $<$ LOQ & $0.001 \pm 0.001$ & $0.002 \pm 0.002$ \\
\hline \multicolumn{6}{|c|}{ Flowers - incurred residues $(\mu \mathrm{g} /$ single flower) } \\
\hline May 15 & $0.004 \pm 0.004$ & $<$ LOQ & $0.002 \pm 0.001$ & $0.012 \pm 0.018$ & $0.002 \pm 0.003$ \\
\hline May 20 & $0.004 \pm 0.003$ & $0.001 \pm 0.001$ & $<\mathrm{LOQ}$ & $0.008 \pm 0.015$ & $0.013 \pm 0.009$ \\
\hline May 29 & $0.003 \pm 0.002$ & $<$ LOQ & $<\mathrm{LOQ}$ & $0.006 \pm 0.012$ & $0.004 \pm 0.003$ \\
\hline June 10 & $0.002 \pm 0.000$ & $<\mathrm{LOQ}$ & $<\mathrm{LOQ}$ & $<\mathrm{LOQ}$ & $0.001 \pm 0.002$ \\
\hline \multicolumn{6}{|c|}{ Leaves - surface residues $\left(\mu \mathrm{g} / \mathrm{cm}^{2}\right)$} \\
\hline May 15 & $0.027 \pm 0.012$ & $0.022 \pm 0.014$ & $0.016 \pm 0.009$ & $0.002 \pm 0.003$ & $0.042 \pm 0.029$ \\
\hline May 20 & $0.001 \pm 0.001$ & $0.018 \pm 0.011$ & $0.006 \pm 0.000$ & $0.001 \pm 0.002$ & $0.038 \pm 0.028$ \\
\hline May 29 & $0.003 \pm 0.002$ & $0.002 \pm 0.002$ & $0.005 \pm 0.003$ & $<\mathrm{LOQ}$ & $0.016 \pm 0.044$ \\
\hline June 10 & $0.004 \pm 0.003$ & $0.001 \pm 0.001$ & $0.005 \pm 0.004$ & $<\mathrm{LOQ}$ & $0.014 \pm 0.013$ \\
\hline \multicolumn{6}{|c|}{ Soil from a $20 \mathrm{~cm}$ profile $(\mu \mathrm{g} / \mathrm{kg})$} \\
\hline May 15 & $14.2 \pm 6.3$ & $16.2 \pm 9.3$ & $<\mathrm{LOQ}$ & $<\mathrm{LOQ}$ & $14.5 \pm 9.0$ \\
\hline May 20 & $4.8 \pm 2.9$ & $9.1 \pm 8.8$ & $<\mathrm{LOQ}$ & $<\mathrm{LOQ}$ & $11.5 \pm 9.7$ \\
\hline May 29 & $6.4 \pm 1.3$ & $5.2 \pm 2.5$ & $<\mathrm{LOQ}$ & $<\mathrm{LOQ}$ & $8.0 \pm 7.2$ \\
\hline June 10 & $7.0 \pm 6.2$ & $3.7 \pm 2.9$ & $<\mathrm{LOQ}$ & $<\mathrm{LOQ}$ & $4.6 \pm 2.6$ \\
\hline \multicolumn{6}{|c|}{ Worker honeybees $(\mu \mathrm{g} / \mathrm{kg})$} \\
\hline May 15 & $4.2 \pm 1.2$ & $<\mathrm{LOQ}$ & $<\mathrm{LOQ}$ & $1.2 \pm 0.8$ & $0.6 \pm 0.7$ \\
\hline May 20 & $19.5 \pm 23.4$ & $<\mathrm{LOQ}$ & $<\mathrm{LOQ}$ & $0.8 \pm 1.7$ & $0.6 \pm 0.8$ \\
\hline May 29 & $4.1 \pm 3.2$ & $<\mathrm{LOQ}$ & $<\mathrm{LOQ}$ & $<$ LOQ & $0.5 \pm 0.4$ \\
\hline June 10 & $1.9 \pm 1.9$ & $<\mathrm{LOQ}$ & $<\mathrm{LOQ}$ & $<\mathrm{LOQ}$ & $<$ LOQ \\
\hline \multicolumn{6}{|c|}{ Worker brood $(\mu \mathrm{g} / \mathrm{kg})$} \\
\hline May 15 & $1.7 \pm 1.1$ & $<\mathrm{LOQ}$ & $<\mathrm{LOQ}$ & $<\mathrm{LOQ}$ & $<$ LOQ \\
\hline May 20 & $1.8 \pm 1.6$ & $0.9 \pm 1.8$ & $<\mathrm{LOQ}$ & $<\mathrm{LOQ}$ & $<$ LOQ \\
\hline May 29 & $2.8 \pm 3.2$ & $<\mathrm{LOQ}$ & $<\mathrm{LOQ}$ & $<\mathrm{LOQ}$ & $<$ LOQ \\
\hline June 10 & $<\mathrm{LOQ}$ & $<\mathrm{LOQ}$ & $<\mathrm{LOQ}$ & $<\mathrm{LOQ}$ & $<$ LOQ \\
\hline \multicolumn{6}{|l|}{ Honey $(\mu \mathrm{g} / \mathrm{kg})$} \\
\hline May 15 & $0.8 \pm 0.5$ & $<\mathrm{LOQ}$ & $<\mathrm{LOQ}$ & $<\mathrm{LOQ}$ & $0.7 \pm 0.8$ \\
\hline May 20 & $0.6 \pm 0.0$ & $<\mathrm{LOQ}$ & $<\mathrm{LOQ}$ & $<\mathrm{LOQ}$ & $<\mathrm{LOQ}$ \\
\hline May 29 & $0.6 \pm 0.3$ & $<\mathrm{LOQ}$ & $<\mathrm{LOQ}$ & $0.5 \pm 0.6$ & $<\mathrm{LOQ}$ \\
\hline June 10 & $<\mathrm{LOQ}$ & $<\mathrm{LOQ}$ & $<\mathrm{LOQ}$ & $0.5 \pm 1.0$ & $<$ LOQ \\
\hline
\end{tabular}

Plantation 1

Eight formulations (four insecticides and four fungicides) containing 10 active ingredients were used at plantation 1 (Table 1). Because it was not possible to detect all studied active substances with the $\mu \mathrm{ECD}$ detector, mepiquat chloride and metconazole (AIs of Caryx 240 SL) were not determined (Tables 2-3). 


\section{Plantation 2}

At plantation 2, 6 preparations (three insecticides and three fungicides) containing eight AIs were used (Table 4). Because it was not possible to detect all studied active substances with the $\mu \mathrm{ECD}$ detector, thiophanatemethyl (AI of Topsin $500 \mathrm{SC}$ ) and paclobutrazole (AI of Toprex 375 SC) were not analysed (Table 5).

\section{Chloropyrifos Residues}

Chloropyrifos, a systemic insecticide from phosphoorganic compounds, was found in all samples of plant material collected from plantation 1 (Field 1: up to $0.017 \mu \mathrm{g} /$ flower for residues on the flower surface, $0.007 \mu \mathrm{g} /$ flower for incurred residues in the flower, and $0.018 \mu \mathrm{g} / \mathrm{cm}^{2}$ of leaves; Field 2: $0.018 \mu \mathrm{g} /$ flower surface - Tables 2-3), and at plantation 2 (up to $0.01 \mu \mathrm{g} /$ flower for residues on the flower surface, $0.004 \mu \mathrm{g} /$ flower for incurred residues in the flower, and $0.027 \mu \mathrm{g} / \mathrm{cm}^{2}$ of leaves - Table 5), as well as in all samples of worker bees and in the majority of brood and honey samples. The residues of this substance ranged from 2.4 to $10.2 \mu \mathrm{g} / \mathrm{kg}$ and from 1.9 to $19.5 \mu \mathrm{g} / \mathrm{kg}$ in bees, from 0.5 to 3.4 and from below LOQ to $2.8 \mu \mathrm{g} / \mathrm{kg}$ in brood, and from 0.6 to $1.7 \mu \mathrm{g} / \mathrm{kg}$ and from below LOQ to $0.8 \mu \mathrm{g} / \mathrm{kg}$ in honey (plantations 1 and 2, respectively). The obtained results clearly indicate that chlorpyrifos content in worker bee and brood tissues increases slightly later than residue levels of this compound in the crop (Tables 2 and 5).

Chlorpyrifos was found in the soil at a level of up to $20.1 \mu \mathrm{g} / \mathrm{kg}$ of soil in plantation 1 and $14.2 \mu \mathrm{g} / \mathrm{kg}$ in plantation 2. This situation is explained by the fact that the PPP was applied at a time when full plant coverage had not yet developed, i.e., on 10 April at plantation 1 and on 23 March at plantation 2. During the whole sampling period and during a few weeks earlier there was no rain that could otherwise wash the formulations from plants to the soil. The presence of this compound in all leaf and flower samples at plantations 1 and 2 (Tables 2-3,5) could be associated with the above circumstances, because the AI might have been absorbed secondarily from the soil by a root system and distributed with water throughout a plant.

\section{Synthetic Pyrethroid Residues}

Three substances from the group of synthetic pyrethroids were assayed in the collected samples: esfenvalerate and deltamethrin used solely at plantation 1, and cypermethrin, used at both plantations (Tables 1-5).

Despite the fact that pyrethroids are insecticides having a surface effect, their residues were also found in plant tissues. In flowers collected from plantation 1, esfenvalerate residue levels on the surface and inside the flowers reached 0.012 and $0.001 \mu \mathrm{g} /$ single flower, respectively. On the leaf surface these values were within the range of 0.001 up to $0.039 \mu \mathrm{g} / \mathrm{cm}^{2}$. Small amounts of esfenvalerate were also found in soil on plantation 1 (up to $10.2 \mu \mathrm{g} / \mathrm{kg}$ ), in bee bodies (to $2.5 \mu \mathrm{g} / \mathrm{kg}$ b.w.), and, on 28 May, also in brood $(0.2 \mu \mathrm{g} / \mathrm{kg}$ b.w.; Table 2$)$.

At plantation 1 the cypermethrin residues were found on the surface (on three sampling dates) and inside (only on 11 June) of the flowers (up to 0.018 and $0.001 \mu \mathrm{g} /$ single flower, respectively) and on leaf surface (up to $0.012 \mathrm{mg} / \mathrm{cm}^{2}$ of leaves on 21 May), in bee bodies (on two dates), and in honey (up to $0.3 \mu \mathrm{g} / \mathrm{kg}$ of worker honeybee bodies, on $21 \mathrm{May}$, and up to $0.4 \mu \mathrm{g} / \mathrm{kg}$ of honey on the same day; Table 2). At plantation 2 the cypermethrin residues were found on the surface of flowers at two sampling dates (up to $0.003 \mu \mathrm{g} /$ single flower), in samples in flower tissue (to $0.002 \mu \mathrm{g} /$ single flower on one day, 15 May), and on the leaf surface (up to $0.016 \mu \mathrm{g} / \mathrm{cm}^{2}$ of leaves). The substance was not present $(>\mathrm{LOQ})$ in the samples of soil, worker honeybees, brood, and honey (Table 5).

At plantation 1 the deltamethrin residues at a level above LOQ were found in several samples only on the surface of leaves and flowers (up to $0.007 \mu \mathrm{g} /$ single flower and $0.016 \mu \mathrm{g} / \mathrm{cm}^{2}$ of leaves), in soil (up to $21.8 \mu \mathrm{g} / \mathrm{kg}$ ), and in small amounts in a few samples of the brood (up to $0.2 \mu \mathrm{g} / \mathrm{kg}$ of brood, on 14 May; Table 2).

The residues of esfenvalerate and deltamethrin were also found on the surface of flowers collected at plantation 1 from field 2 (up to 0.003 and $0.01 \mu \mathrm{g} /$ flower, respectively; Table 3).

Small amounts of pyrethroid residues on the surface of flowers and in the samples collected from hives (Tables 2 and 5) indicate that treatments were performed in accordance with the principles of good agricultural practice - in the evenings, when bees did not forage and flowers were closed.

\section{Fungicide Residues}

In the present study we included fungicides difenoconazole, flutriafol, and cyproconazole from the triazole group, and picoxystrobin and azoxystrobin from the strobilurine group. The studied substances are characterised by contact, translaminar, or systemic modes of action. The systemic action significantly prolongs the effect of a preparation.

At plantation 1 (Table 2), small amounts of difenoconazole (up to $0.002 \mu \mathrm{g} /$ single flower) and very large amounts of picoxystrobin (up to $0.047 \mu \mathrm{g} / \mathrm{single}$ flower) and flutriafol (up to $0.058 \mu \mathrm{g} / \mathrm{single}$ flower, only on 14 May) were found on the flower surface. The difenoconazole residues inside flowers from samples collected on 14 May amounted to $0.003 \mu \mathrm{g} / \mathrm{single}$ flower, while flutriafol residues in samples collected on 21 May reached $0.012 \mu \mathrm{g} / \mathrm{single}$ flower. On the leaf surface in samples collected on 14 May picoxystrobin and flutriafol reached $0.018 \mu \mathrm{g} / \mathrm{cm}^{2}$ and $0.021 \mathrm{mg} / \mathrm{cm}^{2}$, respectively. Difenoconazole was not detected on the leaf surface, indicating that the systemic AI reached the flowers indirectly after earlier storage in the plant tissues. 
Difenoconazole was found in all samples of bee bodies (up to $2.0 \mu \mathrm{g} / \mathrm{kg}$ of worker honeybees), in three samples of the brood, and in four samples of honey (up to $1.9 \mu \mathrm{g} / \mathrm{kg}$ and $1.9 \mu \mathrm{g} / \mathrm{kg}$ in brood and honey, respectively). Flutriafol was found only once in the worker honeybee samples (25.5 $\mu \mathrm{g} / \mathrm{kg}$ on 3 June). It was probably transported by bees from field 2, where an increase in the residue levels up to $0.011 \mu \mathrm{g} / \mathrm{single}$ flower was found in samples collected in 3 June (Table 3). This significant increase of the pollutant concentrations in bees suggests that the treatment was performed during the foraging period, and bees were directly exposed to the applied liquid. Its residues were not found in the samples of brood and honey. Picoxystrobin in the amount above LOQ was not detected in bees or in honey, but was found twice in the brood (up to $7.3 \mu \mathrm{g} / \mathrm{kg}$ of brood on 28 May).

Small amounts of difenoconazole and larger amounts of picoxystrobin and flutriafol were noted also on the flowers collected from planation 1, field 2 (up to 0.001, 0.012 , and $0.013 \mu \mathrm{g} /$ single flower, respectively; Table 3 ).

Cyproconazole used at plantation 2 (Table 5) on 8 May remained on the flower surface and internally (up to $0.035 \mu \mathrm{g} / \mathrm{single}$ flower on $15 \mathrm{May}$, and $0.001 \mu \mathrm{g} / \mathrm{single}$ flower on 20 May, respectively), on the leaf surface (on all the sampling days: up to $0.022 \mu \mathrm{g} / \mathrm{cm}^{2}$ of leaves), in soil (up to $16.2 \mu \mathrm{g} / \mathrm{kg}$ ), and in brood samples $(0.9 \mu \mathrm{g} / \mathrm{kg}$ only on 20 May). Its presence at the level exceeding LOQ was not noted in the samples of bees and honey.

Difenoconazole was present on the flower surface in all samples (up to $0.029 \mu \mathrm{g} /$ single flower), inside the flowers (on three sampling days, up to $0.012 \mu \mathrm{g} /$ single flower), on leaves (on two sampling days, up to $0.002 \mu \mathrm{g} / \mathrm{cm}^{2}$ of leaves), in worker honeybee bodies and in honey (on three and two sampling days, up to $1.2 \mu \mathrm{g} / \mathrm{kg}$ and $0.5 \mu \mathrm{g} / \mathrm{kg}$ of worker honeybees and honey, respectively). The presence of difenoconazole residues in the brood and in soil was not detected. High difeconazole residue levels inside and on the surface of flowers $(0.029 \mu \mathrm{g} /$ single flower and $0.015 \mu \mathrm{g} /$ single flower, respectively), versus the residue levels of this AI on the leaf surface $\left(0.002 \mu \mathrm{g} / \mathrm{cm}^{2}\right.$ of leaves) implies its possible very good absorption and, consequently, transport to and deposition in developing flowers followed by excretion on the flower's surface together with pollen and nectar. During this period the inflorescences were not yet developed. Rapeseed and inflorescences have a relatively compact surface on which a large part of the preparations used during the flowering period remains.

Azoxystrobin was present on the surface of all the flowers (up to $0.037 \mu \mathrm{g} / \mathrm{single}$ flower). The maximum residue inside the flowers appeared with a slight delay (reaching a maximum value of $0.13 \mu \mathrm{g} / \mathrm{kg}$ on 20 May), which suggests that this AI needs time to spread inside the plant along with the juices, as well as to be absorbed from leaf surface, and from the soil, from which it can be collected by roots. Significant residue levels of this substance were detected in all the studied samples (up to $0.042 \mu \mathrm{g} / \mathrm{cm}^{2}$ of leaves). In the samples collected on all three sampling dates, azoxystrobin residues were observed in the worker honeybee bodies (up to $0.6 \mu \mathrm{g} / \mathrm{kg}$, on 15 and 20 May), as well as in honey samples collected on 15 May $(0.7 \mu \mathrm{g} / \mathrm{kg})$.

Small amounts of fungicides in the samples collected from the hives (apart from difeconazole at plantation 1) suggest that these preparations were used at hours when no bees were foraging.

\section{Hazards to Bees}

Our experiments showed that the bees visiting rapeseed crops might have contact with all insecticides that are extremely dangerous for them, and fungicide preparations having a relatively less detrimental effect. They also could collect them through nectar. In most cases the AIs of the used PPPs were characterised by the systemic or translaminar modes of action. This means that their residues were present not only on the plant surface, but also that they could move across the plants through their conductive system, penetrating into nectar and pollen collected by $A$. mellifera. This could explain numerous residues noted in the hive (Tables 2-3, 5). Also, weather conditions during the study (air temperature reaching $30^{\circ} \mathrm{C}$ during the day and significant soil dryness followed by heavy rainfalls) could influence the obtained results, affecting both nectar secretion by plants and their blossoming intensity. This in turn influenced the total surface area of flowers on which the applied compounds were deposited, as well as the foraging activity of bees and AI residue levels on plants and in soil (resulting from physical factors, for example, and washout, as well as from those influencing physicochemical and biochemical changes in active substances).

As A. mellifera is characterised by the presence of only 46 genes responsible for the detoxification processes following exposure to PPPs [12], and its cytochrome fraction has very low activity [3], it is susceptible to pesticide effects to a considerable extent. This susceptibility additionally depends on the time of day of their exposure [13-15], their age [16], and diet [17]. Even sub-lethal doses of those preparations can be harmful to bees by affecting their cognitive abilities [18-20] and modifying their resistance to pathogens and parasites [21-23]. They can also disturb the protein action in the nervous system [24] or modify feeding behaviour [25]. PPPs are also indicated, besides other factors [26-27], as one of the main reasons for colony losses [28].

Our study was limited to one month only, and during this period there were no clear-cut declines in the strength of the tested honeybee colonies. However, the very fact of presence of insecticidal pollutants in the hive, and also in honey (chlorpyrifos at plantations 1 and 2, and cypermethrin at plantation 1; Tables 2, 5), indicates that bees could have been exposed to these compounds for a longer time and at various developmental stages. This is also important, because AIs of PPPs may be toxic to honeybees even at sub-lethal doses [29], or they can act synergistically [30-32]. Thompson (1996) [32] suggested that even PPPs considered safe to bees 
could intensify the toxic action against those insects by two orders of magnitude when used in combination with other PPPs. It should therefore be emphasised that in the present study the honeybees were exposed to five AIs from insecticides (chlorpyrifos, thiacloprid, deltamethrin, cypermethrin, esfenvalerate) and five AIs from fungicides (difenoconazole, mepiquat chloride, metconazole, flutriafol, picoxystrobin) on plantation 1, and three AIs from insecticides (chlorpyrifos, cypermethrin, acetamiprid) and five AIs from fungicides (thiophanate-methyl, difenoconazole, paclobutrazol, azoxystrobin, cyproconazole) on plantation 2, as well as their adjuvants, which increase the probability of adverse interactions between them. The synergism phenomenon occurs, for instance, in the case of pyrethroids and difenoconazole, as observed by Thompson and Wilkins (2003) [31], or acetamipride and triazole [4], and the similar combinations of AIs of PPPs could also appear in bees that we examined (Tables 2-3, $5)$.

\section{Consumer Exposure to Pesticide Residues in Honey}

In developing countries where legal and organizational constraints in the marketing and use of plant protection products are much less stringent than in the EU, it is likely that residues of plant protection products in honey exceed the MRLs [33]. Also in Poland, where amateur beekeeping dominates and significant quantities of honey are sold without proper control, there are cases of overruns. In the present study the residues of three compounds were found in honey from plantation 1: chlorpyrifos, cypermethrin, difenoconazole, and in honey from plantation 2: chlorpyrifos, difenoconazole, and azoxystrobin. In no case did the MRLs exceed (Tables 1, 4) - for chlorpyrifos, percentage MRL (Equation 1) reached maximum $3.4 \%$ at plantation 1 and $1.6 \%$ at plantation 2 , percentage MRL was $3.8 \%$ and $1.0 \%$ for difenoconazole (plantations 1 and 2, respectively), $0.8 \%$ for cypermethrin (plantation 1), and $1.4 \%$ for azoxystrobin (plantation 2 ).

For the determined AIs in honey collected from both plantations, ADIs were not exceeded (Tables 1, 4). At plantation 1, percentage ADI (Equation 2) was 0.004 for chlorpyrifos, 0.0002 for cypermethrin, and 0.0004 for difenoconazole. At plantation 2, maximum percentage ADI for honey reached 0.002 for chlorpyrifos and 0.0001 for difenoconazole and azoxystrobin.

The safe level of honey consumption was calculated (Equation 3) using values shown in Table 2, and was shown to be $45 \mathrm{~kg}$ for chlorpyrifos residues, 9,500 $\mathrm{kg}$ for cypermethrin, and $400 \mathrm{~kg}$ for difenoconazole. Analogically, at plantation 2 (Table 5), ADI would be exceeded when the amount of consumed honey is $95 \mathrm{~kg}$ for chlorpyrifos, $1,520 \mathrm{~kg}$ for difenoconazole, and 2,171 kg for azoxystrobin.

Our results indicate that in terms of the studied PPPs, honey is completely safe for consumption. Such low residue levels, as noted in our study, could be related to the fact that the owners of the rapeseed fields were also the owners of the researched apiaries, so it was in their interest to carry out treatments that would not cause bee losses or negatively affect the quality of the honey.

\section{Conclusions}

The residues of all the studied AI of PPPs were detected at surveyed plantations 1 two.

A transfer of plant protection products from rapeseed crops to the bee hives was proven: for studied AIs found in bee bodies, five of seven (chlorpyrifos, esfenvalerate, cypermethrin, difenoconazole, flutriafol) were detected at plantation 1, and three of five (chlorpyrifos, difenoconazole, azoxystrobin) were found at plantation 2. Analogically, five AIs (chlorpyrifos, esfenvalerate, difenoconazole, picoxystrobin, and deltamethrin) were detected in the brood at plantations 1 and two AIs (chlorpyrifos, cyproconazole) were found in the brood at plantation 2. In honey from plantations 1 and 2 , three AIs (chlorpyrifos, cypermethrin, difenoconazole and chlorpyrifos, difenoconazole, and azoxystrobin, respectively) were detected.

Residues of PPPs in the examined honey did not exceed the acceptable MRL, which means that this product is safe for consumption.

\section{References}

1. CSO (CENTRAL STATISTICAL OFFICE). Production of agricultural and horticultural crops in 2015. Agriculture Department, Zakład Wydawnictw Statystycznych, Warszawa, 2016. Available online: http://stat.gov.pl/download/gfx/portalinformacyjny/ pl/defaultaktualnosci/5509/9/14/1/produkcja_upraw_ rolnych_i_ogrodniczych_w_2015.pdf (accessed on 27.06.2017)

2. GWIAZDOWSKI R. Choroby i ochrona rzepaku ozimego. Instytut Hodowli i Aklimatyzacji Roślin-Państwowy Instytut Badawczy, 2004. Available online: http://www. ihar.edu.pl/download.php?id=1681 (accessed on 27.06.2017)

3. THE HONEYBEE GENOME SEQUENCING CONSORTIUM. Insights into social insects from the genome of the honeybee Apis mellifera. Nature. 443, 931, 2006.

4. IWASA T., MOTOYAMA N., AMBROSE J.T., ROE R.M. Mechanism for the differential toxicity of neonicotinoid insecticides in the honey bee, Apis mellifera. Crop Prot. $\mathbf{2 3}$ (5), 371, 2004.

5. CHAUZAT M.-P., CARPENTIER P., MARTEL A.-C., BOUGEARD S., COUGOULE N., PORTA P., LACHAIZE J., MADEC F., AUBERT M., FAUCON J.-P. Influence of pesticide residues on honey bee (Hymenoptera: Apidae) colony health in France. Environ. Entomol. 38 (3), 514, 2009.

6. SADŁO S., SZPYRKA E., PIECHOWICZ B., GRODZICKI P. A case study on toxicological aspects of the pest and disease control in the production of the high-quality raspberry (Rubus idaeus L.). J. Environ. Sci. Health. 50 (1), 8, 2015. 
7. PIECHOWICZ B., SADŁO S., SZPYRKA E., STAWARCZYK K., STAWARCZYK M., GRODZICKI P. Disappearance of some fungicides in mature apples immediately before supplying fruit to the consumer. Fresen. Environ. Bull. 25 (10), 4246, 2016.

8. EU Pesticide Database, 2017. Available online: http:// ec.europa.eu/food/plant/pesticides/eu-pesticides-database/ public/?event $=$ activesubstance . selection $\&$ language $=\mathrm{EN}$ (accessed on 27.06.2017)

9. CSO (CENTRAL STATISTICAL OFFICE). Agriculture in 2015. Departament Rolnictwa. Zakład Wydawnictw Statystycznych, Warszawa, 2016. Available online: http:// stat.gov.pl/download/gfx/portalinformacyjny/pl/defaultaktualnosci/5507/3/12/1/rolnictwo_w_2015.pdf (accessed on 27.06.2017)

10. CSO (CENTRAL STATISTICAL OFFICE). Agriculture in 2015. Demographic yearbook of Poland. Zakład Wydawnictw Statystycznych, Warszawa, 2016. Available online: http://stat.gov.pl/download/gfx/portalinformacyjny/ pl/defaultaktualnosci/5515/3/10/1/rocznik_demograficzny_2016.pdf (accessed on 27.06.2017)

11. DOCUMENT SANTE. Guidance document on analytical quality control and method validation procedures for pesticides residues analysis in food and feed. SANTE/11945/2015. 2015. Available online: https://ec.europa.eu/food/sites/food/ files/plant/docs/pesticides_mrl_guidelines_wrkdoc_11945. pdf (accessed on 27.06.2017)

12. CLAUDIANOS C., RANSON H., JOHNSON R.M., BISWAS S., SCHULER M.A., BERENBAUM M.R., FEYEREISEN R., OAKESHOTT J.G. A deficit of detoxification enzymes: pesticide sensitivity and environmental response in the honeybee. Insect Mol. Biol. 15 (5), 615, 2006.

13. PIECHOWICZ B., GRODZICKI P., STAWARCZYK K., PIECHOWICZ I., STAWARCZYK M., ZWOLAK A. Circadian and seasonal changes in honeybee (Apis mellifera) worker susceptibility to pyrethroids. Pol. J. Environ. Stud. 25 (3), 1177, 2016.

14. PIECHOWICZ B., GRODZICKI P., STAWARCZYK M., STAWARCZYK K. Circadian and seasonal changes in honeybee (Apis mellifera) worker susceptibility to diazinon, teflubenzuron, pirimicarb, and indoxacarb. Pol. J. Environ. Stud. 22 (5), 1457, 2013.

15. PIECHOWICZ B., STAWARCZYK K., STAWARCZYK M. Circadian changes in susceptibility of young honeybee workers to intoxication by pyrethroid, carbamate, organophosphorus, benzoyl urea and pyridine derivative insecticides. J. Plant. Prot. Res. 52 (2), 286, 2012.

16. RINKEVICH F.D., MARGOTTA J.W., PITTMAN J.M., DANKA R.G., TARVER M.R., OTTEA J.A., HEALY K.B. Genetics, synergists, and age affect insecticide sensitivity of the honey bee, Apis mellifera. PLoS One, DOI:10.1371/ journal.pone.0139841, 2015.

17. HARPE J.R., HEYDEN L.C. Honey bee colony collapse disorder is possibly caused by a dietary pyrethrum deficiency. Biosci. Hypotheses. 2 (6), 439, 2009.

18. PIIROINEN S., GOULSON D. Chronic neonicotinoid pesticide exposure and parasite stress differentially affects learning in honeybees and bumblebees. Proc. R. Soc. B. 283, 1,2016

19. WILLIAMSON S.M., WRIGHT G.A. Exposure to multiple cholinergic pesticides impairs olfactory learning and memory in honeybees. J. Exp. Biol. 216, 1799, 2013.
20. STANLEY D.A., SMITH K.E., RAINE N.E. Bumblebee learning and memory is impaired by chronic exposure to a neonicotinoid pesticide. Sci. Rep. 5, 16508, 2015. doi:10.1038/srep16508

21. SÁNCHEZ-BAYO F., GOULSON D., PENNACCHIO F., NAZZI F., GOKA K., DESNEUX N. Are bee diseases linked to pesticides? - A brief review. Environ. Int. 89-90, 7, 2016.

22. PETTIS J.S., VAN ENGELSDORP D., JOHNSON J., DIVELYL G. Pesticide exposure in honey bees results in increased levels of the gut pathogen Nosema. Naturwissenschaften, 99 (2), 153, 2012.

23. VIDAU C., DIOGON M., AUFAUVRE J., FONTBONNE R., VIGUES B., BRUNET J.L., TEXIER C., BIRON D.G., BLOT N., EL ALAOUI H., BELZUNCES L., DELBAC F. Exposure to sublethal doses of fipronil and thiacloprid highly increases mortality of honeybees previously infected by Nosema ceranae. PLoS One. 6 (6), e2 1550, 2011.

24. ROAT T.C., DOS SANTOS-PINTO J.R., DOS SANTOS L.D., SANTOS K.S., MALASPINA O., PALMA M.S. Modification of the brain proteome of Africanized honeybees (Apis mellifera) exposed to a sub-lethal doses of the insecticide fipronil. Ecotoxicology. 23 (9),1659, 2014.

25. HENRY M., BÉGUIN M., REQUIER F., ROLLIN O., ODOUX J.-F., AUPINEL P., APTEL J., TCHAMITCHIAN S., DECOURTYE A. A common pesticide decreases foraging success and survival in honey bees. Science. 336 (6079), 348,2012

26. BACANDRITSOS N., GRANATO A., BUDGE G., PAPANASTASIOU I., ROINIOTI E., CALDON M., FALCARO C., GALLINA A., MUTINELLI F. Sudden deaths colony population decline in Greek honey bee colonies. J. Invertebr. Pathol. 105 (3), 335, 2010.

27. PAXTON R.J. Does infection by Nosema ceranae cause "Colony Collapse Disorder" in honey bees (Apis mellifera)? J. Apicult. Res. 49 (1), 80, 2010.

28. JOHNSON R.M., ELLIS M.D., MULLIN C.A., FRAZIER M. Pesticides and honey bee toxicity - USA. Apidologie. 41, 312, 2010.

29. CRESSWELL J.E., PAGE C.J., UYGUN M.B., HOLMBERGH M., LI Y., WHEELER J.G., LAYCOCK I., POOKC J., DE IBARRA N.H., SMIRNOFF N., TYLER C.R. Differential sensitivity of honey bees and bumble bees to a dietary insecticide (imidacloprid). Zoology (Jena) 115 (6), 365, 2012

30. GLAVAN G., BOŽIČ J. The synergy of xenobiotics in honey bee Apis mellifera: mechanisms and effects. Acta Biol. Slov. 56 (1), 11, 2013.

31. THOMPSON H.M., WILKINS S. Assessment of the synergy and repellency of pyrethroid/fungicide mixtures. Bull. Insectol. 56 (1), 131, 2006.

32. THOMPSON H.M. Interactions between pesticides; a review of reported effects and their implications for wildlife risk assessment. Ecotoxicology. 5 (2), 59, 1996.

33. RISSATO S.R, GALHIANE M.S., DE ALMEIDA M.V., GERENUTTI M., APON B.M. Multiresidue determination of pesticides in honey samples by gas chromatographymass spectrometry and application in environmental contamination. Food Chem. 101 (4), 1719, 2007. 